\title{
Active $\beta$-Amyloid Immunization Restores Spatial Learning in PDAPP Mice Displaying Very Low Levels of $\beta$-Amyloid
}

\author{
Guiquan Chen, ${ }^{1}$ Karen S. Chen, ${ }^{2}$ Dione Kobayashi, ${ }^{2}$ Robin Barbour, ${ }^{2}$ Ruth Motter, ${ }^{2}$ Dora Games, ${ }^{2}$ Stephen J. Martin, ${ }^{1}$ \\ and Richard G. M. Morris ${ }^{1}$ \\ ${ }^{1}$ Laboratory for Cognitive Neuroscience, Centre for Cognitive and Neural Systems, Edinburgh EH8 9JZ, United Kingdom, and ${ }^{2}$ Elan Pharmaceuticals, South \\ San Francisco, California 94080
}

\begin{abstract}
The behavioral and biochemical impact of active immunization against human $\beta$-amyloid $(\mathrm{A} \beta)$ was assessed using male transgenic $(\mathrm{Tg})$ mice overexpressing a human mutant amyloid precursor protein (heterozygous PDAPP mice) and littermate controls. Administration of aggregated $\mathrm{A} \beta_{42}$ occurred at monthly intervals from 7 months ("prevention") or 11 months ("reversal"), followed by double-blind behavioral training at 16 months on a cued task, then serial spatial learning in a water maze. Using a $2 \times 2$ design, with $\mathrm{A} \beta_{42}$ adjuvanted with MPL-AF (adjuvant formulation of monophosphoryl lipid A) or MPL-AF alone, PDAPP mice were impaired compared with non-Tg littermates on two separate measures of serial spatial learning. Immunization caused no overall rescue of learning but limited the accumulation of total $\mathrm{A} \beta$ and $\mathrm{A} \beta_{42}$ levels in cortex and hippocampus by up to $60 \%$. In immunized PDAPP mice, significant negative correlations were observed between hippocampal and cortical $\mathrm{A} \beta$ levels and learning capacity, particularly in the prevention study, and correlations between learning capacity and antibody titer. Moreover, a subset of PDAPP mice with very low A $\beta$ levels (hippocampal A $\beta$ levels of $<6000 \mathrm{ng} / \mathrm{g}$ or cortical $\mathrm{A} \beta$ levels of $<1000 \mathrm{ng} / \mathrm{g}$ ) was indistinguishable from non-Tg controls. Mice in the prevention study were also rescued from cognitive impairment more effectively than those in the reversal study. The combination of variability in antibody response and differential levels of $A \beta$ accumulation across the population of immunized PDAPP mice may be responsible for success in cognitive protection with only a subset of these animals, but the similarity to the findings of certain human vaccination trials is noteworthy.
\end{abstract}

Key words: Alzheimer's disease; animal models; vaccine; transgenic mouse; water maze; spatial learning

\section{Introduction}

Several animal models of Alzheimer's disease (AD) have been developed to help understand the neural mechanisms of the disease process and to provide platforms for testing novel therapeutics (Bartus et al., 1982; Price et al., 1992; Sisodia, 1992; Games et al., 1995; Duff et al., 1996; Hsiao et al., 1996; Bartus, 2000; Sommer et al., 2000). Because abnormal accumulation of $\beta$-amyloid $(\mathrm{A} \beta), \mathrm{A} \beta$ oligomers, and/or amyloid plaque deposition are each held to play distinctive roles in the neurodegeneration that characterizes various stages of $\mathrm{AD}, \mathrm{A} \beta$ has become a particularly important therapeutic target (Hardy and Allsop, 1991; Selkoe, 1991, 2002).

Schenk et al. (1999) made the novel suggestion of immunizing against the accumulation of $\mathrm{A} \beta$. They observed that amyloid plaque deposition in old PDAPP mice could be prevented when $\mathrm{A} \beta_{42}$ was administered monthly from 2 to 13 months of age and significantly reduced when administered from 11 months of age

\footnotetext{
Received Aug. 25, 2006; revised Dec. 22, 2006; accepted Dec. 27, 2006.

The animals for this study were supplied by Elan Pharmaceuticals; the remainder of the work was supported by the United Kingdom Medical Research Council.

Correspondence should be addressed to Richard G. M. Morris, Centre and Division of Neuroscience, University of

Edinburgh, 1 George Square, Edinburgh EH8 9JZ, UK. E-mail: r.g.m.morris@ed.ac.uk.

K. Chen's present address: Roche Pharmaceuticals, 3431 Hillview Avenue, Palo Alto, CA 94304.

DOI:10.1523/JNEUROSCI.3710-06.2007

Copyright $\odot 2007$ Society for Neuroscience $\quad 0270-6474 / 07 / 272654-09 \$ 15.00 / 0$
}

for 7 months. $A \beta$ antibodies apparently cross the blood-brain barrier, bind to plaques, and activate microglial cells that clear amyloid plaques (Bard et al., 2000). This process has been visualized in the living mouse brain (Bacskai et al., 2001). Alternatively, binding to $\mathrm{A} \beta$ antibodies might generate a peripheral sink (DeMattos et al., 2001), changing the equilibrium between the neurons and plasma to aid the removal of $A \beta$. Active and passive $\mathrm{A} \beta$ immunotherapy have since received widespread attention for possible use in humans (Mattson and Chan, 2003; Nicoll et al., 2003). A "double-blind" clinical trial that was suspended prematurely because of meningoencephalitis in $6 \%$ of the patients (Schenk, 2002; Orgogozo et al., 2003) revealed reduced plaque deposition in brain tissue (Nicoll et al., 2003) and a positive relationship between antibody titer and a lower rate of decline of cognitive function (Gilman et al., 2005).

Several preclinical studies of the impact of immunization on learning and memory in amyloid precursor protein (APP) transgenic mice have shown positive effects. TgCRND8 mice (expressing a mutant human APP695 gene) and non-Tg controls were immunized with $\mathrm{A} \beta_{42}$ from 6 weeks of age for 14 weeks (Janus et al., 2000). A longitudinal design was used with a standard water maze spatial reference memory task. Although still impaired relative to non-Tg controls, $\mathrm{A} \beta$-immunized Tg mice escaped significantly faster than controls during acquisition and showed reduced $\mathrm{A} \beta$ plaque deposition. However, neither genotype nor 
immunization affected posttraining probe tests that measure spatial memory. Morgan et al. (2000) also used a longitudinal design with a radial-arm water maze with untreated non-Tg, $\mathrm{A} \beta$ immunized, or keyhole limpet hemocyanin (KLH)-immunized Tg mice. Before treatment, all three groups displayed good learning at 11.5 months. The animals were retested at 15.5 months after five inoculations at monthly intervals of either $\mathrm{A} \beta$ or KLH. The $\mathrm{A} \beta$-immunized Tg mice showed successful learning almost but not quite as good as the non-Tg mice. The improved rate of learning was explained in terms of reduced levels of soluble $\mathrm{A} \beta$ in the brain, but the number of subjects per group was small. In studies using passive immunization with $\mathrm{A} \beta$ antibodies, positive effects have been seen in object recognition memory in 24month-old PDAPP mice (Dodart et al., 2002) and in water-maze learning using other transgenic mouse models of $\mathrm{AD}$ (Kotilinek et al., 2002; Billings et al., 2005; Hartman et al., 2005; Maier et al., 2006; Wilcock et al., 2006).

The aim of this study was twofold. First, using a large cohort of mice to ensure adequate statistical power, we tested whether active $\mathrm{A} \beta$ immunization could prevent and/or rescue the agerelated learning deficit that is observed in PDAPP mice using a serial spatial learning task (Chen et al., 2000). This is a useful new behavioral protocol because, like the radial water-maze task, it engages both encoding and retrieval of memory each day, analogous to the episodic memory tasks that are susceptible in early AD. Second, like the clinical study of Gilman et al. (2005), we also examined whether any cognitive rescue would be related to the impact of immunization on $\mathrm{A} \beta$ levels and/or $\mathrm{A} \beta$ titer responses. We anticipated that there may be such a relationship because variation in $\mathrm{A} \beta$ levels in PDAPP mice that massively overexpress mutant APP might not always result in immunization-associated rescue in every animal. In experiment 1 ("prevention"), $A \beta$ immunization of both PDAPP and non-Tg mice was started at 7 months and given at monthly intervals for 9 months. In experiment 2 ("reversal"), PDAPP mice were immunized from 11 months of age for 5 months. After these treatments with $\mathrm{A} \beta_{42}$ plus the adjuvant MPL-AF or adjuvant only, serial spatial learning was examined at 15-16 months together with later measurements of $\mathrm{A} \beta$ levels and $\mathrm{A} \beta$ titer responses.

\section{Materials and Methods}

Subjects. All mice $(n=150)$ were age-matched littermates. The founder of PDAPP mice was generated on a Swiss Webster $\times \mathrm{B}_{6} \mathrm{D}_{2} \mathrm{~F}_{1}(\mathrm{C} 57 \mathrm{BL} / 6 \times$ DBA/2) background (Games et al., 1995). They were bred with mice of the same background for three generations. Generation 3 was bred with $\mathrm{B}_{6} \mathrm{D}_{2} \mathrm{~F}_{1}$. Generation 4 was then bred with Swiss Webster to generate heterozygous animals used for the present study. All PDAPP mice were non-white heterozygous males. In the prevention study (experiment 1 ), 67 mice were tested (PDAPP immunized, $n=17$; PDAPP adjuvant only, $n=17$; non-Tg immunized, $n=17$; non-Tg adjuvant only, $n=16)$. In the reversal study (experiment 2), 83 mice were tested (PDAPP immunized, $n=24$; PDAPP adjuvant only, $n=18$; non-Tg immunized, $n=$ 22 ; non-Tg adjuvant only, $n=19$ ). The mice were group housed (two to four per cage). All phases of the study were conducted blind: the experimenter (G.C.) was blind to both genotype and treatment status, the preliminary data analyses was conducted by someone unconnected with the daily training of the animals (S.J.M.), the posttraining immunological analyses conducted at Elan Pharmaceuticals (South San Francisco, CA) was blind to the behavioral data, and the project leader (R.G.M.M.) was blind to the outcome until all testing was complete.

The water maze. The open-field water maze is $2 \mathrm{~m}$ in diameter and set into a large laboratory room with prominent two- and threedimensional extramaze cues. The water is filled and drained daily, maintained at $25^{\circ} \mathrm{C}$, and made opaque by the addition of $250 \mathrm{ml}$ of latex liquid (Cementone-Beaver, Buckingham, UK). Escape from the water was pro- vided by a single moveable platform of $20 \mathrm{~cm}$ diameter (ratio of pool to platform area of 100:1) that was normally hidden $1.5 \mathrm{~cm}$ beneath the water surface but, during the initial cue training, rendered visible by the addition of a prominent local cue. The mice were gently placed into the water facing the side walls and allowed to swim for up to $90 \mathrm{~s}$ to find and climb onto the platform. The starting position was randomized and counterbalanced. Once found, they stayed there for $30 \mathrm{~s}$ and were then removed by allowing them to jump onto a small paint roller for return to their "transport cage" in which they were placed under a heat lamp. Several mice were trained successively in a group enabling intertrial intervals to be $10 \mathrm{~min}$. For each location trained, the escape platform was in any one of 20 different locations (two series of 10 counterbalanced platform locations). The swimming movements of the mice were tracked using in-house software (Actimetrics Watermaze; Coulbourn Instruments, Allentown, PA), which provides objective, automated video tracking of the animals and a suite of relevant analysis options, including swim path, time spent in target quadrant, thigmotaxis, etc.

Overview of experimental protocol. The two experiments were procedurally identical and consisted of the following phases: (1) immunization; (2) shipping of the animals to Edinburgh; (3) visible platform training (5d); (4) serial spatial learning with a hidden platform (10-20 d); (5) ELISAs for total $\mathrm{A} \beta$ and $\mathrm{A} \beta_{42}$ quantification; and (6) $\mathrm{A} \beta$ antibody titer response measurement.

Phase 1: immunization of the mice. $\mathrm{A} \beta$ peptide was freshly prepared from lyophilized powder for each set of injections. For $A \beta$ immunizations, 2 mg of human $\mathrm{A} \beta_{42}$ (US Peptides, Rancho Cucamonga, CA) was added to $0.9 \mathrm{ml}$ of deionized water, and the mixture was vortexed to generate a relatively uniform suspension. A $100 \mathrm{ml}$ of aliquot of $10 \times$ PBS (in which $1 \times \mathrm{PBS}$ is $0.15 \mathrm{M} \mathrm{NaCl}$ and $0.01 \mathrm{~m}$ sodium phosphate, $\mathrm{pH} 7.5$ ) was added. The suspension was vortexed again and incubated overnight at $37^{\circ} \mathrm{C}$ for use the next day. $\mathrm{A} \beta_{42}$ at $50 \mathrm{mg}$ and $25 \mathrm{mg}$ of the adjuvant MPL-AF in $200 \mathrm{ml}$ of PBS were used for each subcutaneous injection. Injections of $\mathrm{A} \beta_{42}$ and MPL-AF or of MPL-AF alone were made on days 0,14 , and 28 and then once every 4 weeks.

Phase 2: shipping. The mice were shipped by air from San Francisco to Edinburgh with a journey time of $<24 \mathrm{~h}$, followed by 1 week (minimum) of acclimatization to the new housing conditions and diet, as required by United Kingdom Project License requirements to minimize stress.

Phase 3: visible cue task training. There were $5 \mathrm{~d}$ of training, four trials per day, with the platform location changed across trials. Curtains were drawn around the pool to exclude the extramaze cues. The platform was made visible by putting a bronze cylinder on it $(15 \mathrm{~cm}$ high and $3 \mathrm{~cm}$ in diameter). If a mouse failed to get to the platform after $90 \mathrm{~s}$ had elapsed, it was guided to the visible platform by hand.

Phase 4: serial spatial reversal learning with a hidden escape platform. The animals were trained for eight trials per day on a series of spatial tasks ("problems") each consisting of finding the hidden escape platform in the water maze. Training continued until three successive trials occurred with a mean escape latency of $<20 \mathrm{~s}$, a criterion that might be reached within $1 \mathrm{~d}$ or might take $>1 \mathrm{~d}$ to be reached (Fig. 1). Once criterion was reached, training for that day stopped and the animals were switched to a new problem (i.e., new platform location) starting on the next day. Training continued until a minimum of five separate problems had been learned or $10 \mathrm{~d}$ of training, whichever took longer. Two performance measures were derived. "Trials-to-criterion" is a quantitative assessment of the number of trials, inclusive of the criterion run, taken to learn each of the first five spatial locations (as in Fig. 1). "Learning capacity" is a measure of the number of separate locations that an individual mouse learned in $10 \mathrm{~d}$ of training. Both measures show comparable sensitivity to age-related changes in PDAPP mice in cross-sectional and longitudinal experimental protocols (Chen et al., 2000).

Phase 5: ELISA analysis of total $A \beta$ and $A \beta_{42}$. All 150 mice tested in the water maze were killed by cervical dislocation. The brain was quickly removed and put into ice-cold artificial CSF. Two brain areas, hippocampus and cortex, were dissected, weighed, and then put into Eppendorf tubes for homogenization. Guanidine buffer at $5 \mathrm{~m}$ was added to each tube, and the tissue was completely homogenized with a hand-held homogenizer. The brain homogenates were further diluted 1:10 with icecold casein buffer $(0.25 \%$ casein, $0.05 \%$ sodium azide, $20 \mu \mathrm{g} / \mathrm{ml}$ aproti- 
nin, $5 \mathrm{~mm}$ EDTA, pH 8.0, and $10 \mu \mathrm{g} / \mathrm{ml}$ leupeptin in $\mathrm{PBS}$ ) before centrifugation $\left(16,000 \times g\right.$ for $20 \mathrm{~min}$ at $\left.4^{\circ} \mathrm{C}\right)$.

The "total" $\mathrm{A} \beta$ sandwich ELISA consists of the capture antibody 266 , which is specific to amino acids $13-28$ of $A \beta$, and the biotinylated reporter antibody $3 \mathrm{D} 6$, which is specific to amino acids $1-5$ of $A \beta$. The $A \beta_{42}$ sandwich ELISA uses the capture monoclonal antibody 21F12 $\left(\mathrm{A} \beta_{33-42}\right)$. Biotinylated 3D6 is also the reporter antibody in this assay. The 266 and 21F12 monoclonal antibodies were coated at 10 $\mu \mathrm{g} / \mathrm{ml}$ into 96-well immunoassay plates (Costar, Cambridge, MA) overnight at room temperature (RT). The plates were then aspirated and blocked with $0.25 \%$ human serum albumin in PBS buffer for at least $1 \mathrm{~h}$ at RT and then stored desiccated at $4^{\circ} \mathrm{C}$ until use. The plates were rehydrated with wash buffer $(0.05 \%$ Tween 20 in Tris-buffered saline) before use. The samples and standards were added to the plates and incubated at RT for $1 \mathrm{~h}$. The plates were washed three or more times with wash buffer between each step of the assay. The biotinylated 3D6, diluted to $0.5 \mu \mathrm{g} / \mathrm{ml}$ in casein assay buffer $(0.25 \%$ casein and $0.05 \%$ Tween 20, pH 7.4, in PBS), was incubated in the wells for $1 \mathrm{~h}$ at RT. Avidin-horseradish peroxidase (Vector Laboratories, Burlingame, CA), diluted 1:4000 in casein assay buffer, was added to the wells for $1 \mathrm{~h}$ at RT. The colorimetric substrate slow 3,30,5,59-tetramethyl benzidine (TMB) ELISA (Pierce, Rockford, IL) was added and allowed to react for $15 \mathrm{~min}$, after which the enzymatic reaction was stopped with addition of $1 \mathrm{M}$ $\mathrm{H}_{2} \mathrm{SO}_{4}$. Reaction product was quantified using a Molecular Devices (Palo Alto, CA) Vmax spectrophotometer measuring the difference in absorbance at 450 and $650 \mathrm{~nm}$.

Phase 6: ELISA analysis for serum antibodies. Blood samples were collected from all of the 150 mice behaviorally tested. Titers were determined by serial dilutions of sera against aggregated $\mathrm{A} \beta_{42}$ that had been coated onto microtiter wells. Detection used goat antimouse Ig conjugated to horseradish peroxidase and slow TMB (Pierce) substrate. Titers were defined as the dilution yielding $50 \%$ of the maximal signal. All samples and standards were assayed in duplicates.

Data analysis. All behavioral and ELISA data were analyzed using ANOVAs and analyses of covariation. An important feature was an attempt to relate behavioral performance to levels of $A \beta$ and antibody titer in individual animals.

\section{Results}

The animals arrived after the shipment in good health and were required to have a minimum period of 1 week acclimatization to the laboratory in Scotland before testing commenced. All mice quickly adapted to the new housing conditions without difficulty and were housed in groups consisting of three to four littermate males. Animals $(n=150)$ that swam well and completed the experiment were included in this report. A small number of animals, one to two per group and in all groups, were identified as poor swimmers and removed from the study.

\section{Cue task performance}

Immunization did not affect cue task learning in PDAPP or non-Tg mice. Figure 2 shows the decline in mean escape latency from between 23 and $45 \mathrm{~s}$ on day 1 to mean latencies of $5-7 \mathrm{~s}$ by day 5 in all groups of both the prevention $(F=96.2$; df 1.41/89.0; $p<0.001$, Greenhouse-Geisser correction) and reversal $(F=$ 105.9; df 1.76/138.9; $p<0.001)$ experiments. Statistical analysis revealed no significant immunization effect in either study $(F=$ $1.58 ; \mathrm{df}=1 / 63 ; p>0.2$ for prevention; $F<1$ for reversal), but the PDAPP groups were significantly slower to escape overall ( $p$ values $<0.01)$. Highly significant groups $\times$ genotype interactions
A. Prevention study

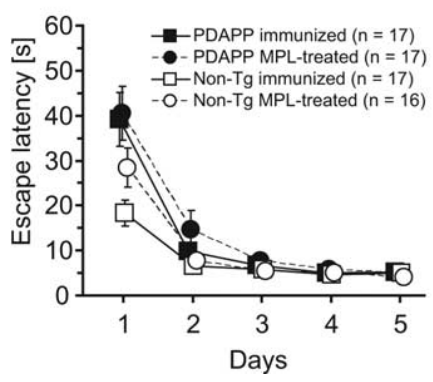

Day 2
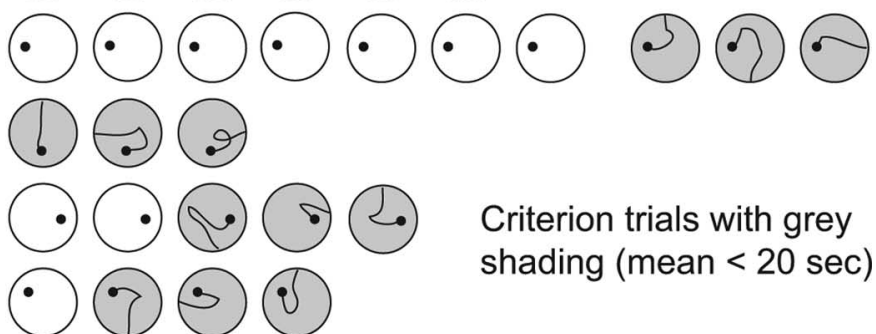

3
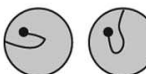

Criterion trials with grey

shading (mean $<20 \mathrm{sec}$ )

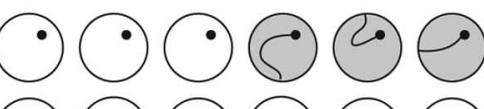

Figure 2. Visible platform learning. $\boldsymbol{A}$, There was no difference in escape latency between the PDAPP and non-Tg groups in the prevention study. $\boldsymbol{B}$, There was a deficit in escape latency in the PDAPP groups on day 1 but not thereafter in the reversal study.

for both the prevention and reversal studies ( $p$ values $<0.005)$ reflected poorer cue task performance of the PDAPP mice on day 1 ( $p$ values $<0.01$ ) but little difference thereafter. All mice were escaping rapidly and consistently by days 4 and 5 . Thus, although there was a transitory impairment, PDAPP mice displayed no lasting deficit in sensorimotor function or motivation to learn.

\section{Serial spatial learning}

When transferred to the serial spatial reversal task, PDAPP mice showed a consistent learning deficit in both the trials-tocriterion and the learning capacity measures of performance. Figure 3, $A$ and $B$ (performance on five individual spatial locations) and $C$ and $D$ (mean trials to criterion), shows the performance of all mice on the first five platform locations that were used to compute the trials-to-criterion measure. For the prevention study, an ANOVA revealed a main transgene effect $(F=13.4 ; \mathrm{df}=1 / 63 ; p<0.001)$ but no overall effect of immunization $(F<1)$. Similarly, in the reversal study, the ANOVA again revealed a main transgene effect $(F=29.7$; $\mathrm{df}=1 / 79 ; p<$ $0.001)$ but again no overall immunization effect $(F<1)$.

The effects of $A \beta$ immunization on spatial learning were also examined using the learning capacity measure, the maximum number of locations learned in $10 \mathrm{~d}$ (Fig. 4). In terms of total number of platform locations learned in $10 \mathrm{~d}$, PDAPP mice were significantly impaired relative to non-Tg mice (prevention, $F=$ $16.9, \mathrm{df}=1 / 63, p<0.001$; reversal, $F=46.5, \mathrm{df}=1 / 79, p<$ $0.001)$. However, no overall effect of immunization was found $(F$ values $<1)$. These results confirm and extend the findings ob- 


\section{Prevention Study}

A. Trials to criterion by problem

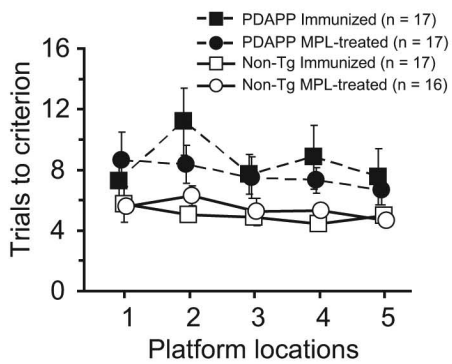

Reversal Study

C. Trials to criterion by problem

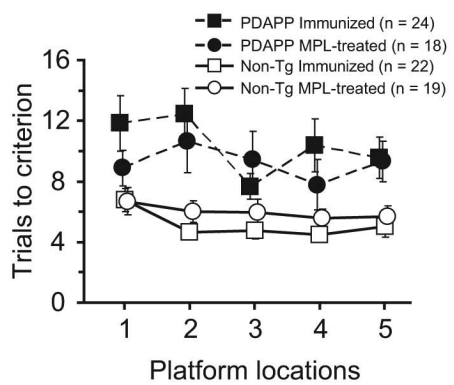

B. Mean trials to criterion

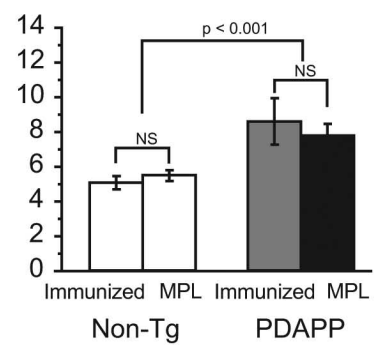

D. Mean trials to criterion

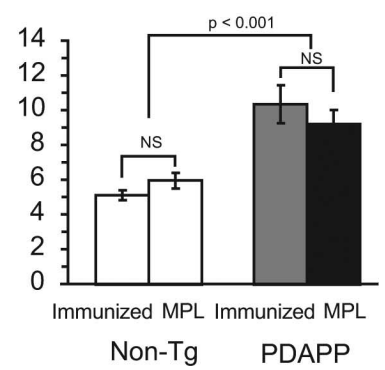

Figure 3. Serial spatial learning: trials to criterion measure. Unlike conventional measures of water-maze spatial learning (which use escape latency), the measure of performance is the number of trials taken to learn each spatial problem across five successive spatial problems. $\boldsymbol{A}$, $\boldsymbol{B}$, Trials to criterion for the prevention study (experiment 1). Plot of performance for each individual platform $(\boldsymbol{A})$ and of mean performance across the five locations $(\boldsymbol{B})$. Overall, the PDAPP groups were impaired, and there was apparently no effect of immunization. $\boldsymbol{C}, \boldsymbol{D}$, Trials to criterion for the reversal study. Plot shows performance for each individual platform and of mean performance across the five locations. Again, the PDAPP groups were impaired, and there was no effect of immunization.

\section{A. Prevention study}

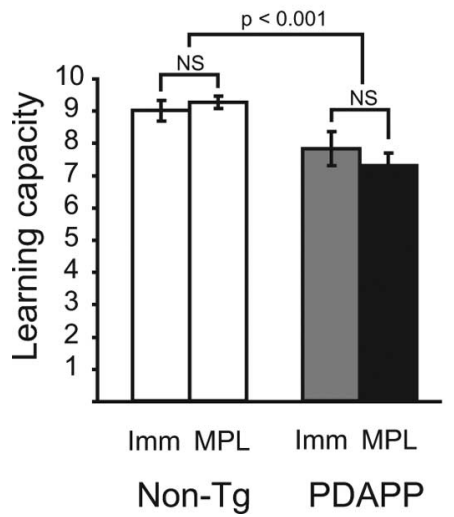

\section{B. Reversal study}

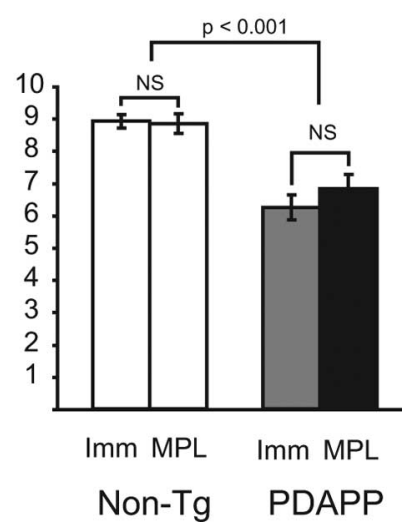

Figure 4. Serial spatial reversal learning: learning capacity measure. Additional training continues for a full $10 \mathrm{~d}$. The learning capacity measure is the total number of spatial locations (problems) learned by each animal over this time. $\boldsymbol{A}$, Prevention study. $\boldsymbol{B}$, Reversal study. The PDAPP mice were impaired, and there was no apparent impact of immunization.

tained with the trials-to-criterion measure of performance over the first five problems trained. Thus, at this stage of the analysis, the data appeared to indicate that $\mathrm{A} \beta$ immunization of PDAPP mice for periods of either 5 or 9 months did not rescue the agerelated impairment in serial spatial learning relative to non-Tg controls. However, comparison of the performance of $\mathrm{A} \beta_{42}$-immunized animals in the prevention and reversal studies revealed better behavioral performance of the PDAPP mice that had received the longer period of $\mathrm{A} \beta_{42}$ treatment $(F=5.97 ; \mathrm{df}=1 / 39 ; p<0.025)$, our first indication that this overall picture was deceptive.

\section{A $\beta$ levels}

Immunization was successful in lowering $A \beta$ levels. After completion of behavioral testing, $A \beta$ levels in the brain were measured using ELISA. Table 1 shows the total $\mathrm{A} \beta$ and $\mathrm{A} \beta_{42}$ levels in the cortex (top) and hippocampus (bottom) of PDAPP mice that were subject to $A \beta$ immunization or MPL-AF only. The pattern across groups is similar for both total $A \beta$ and $A \beta_{42}$. Analysis of the two experiments together, with immunization and treatment period as separate factors, revealed that $\mathrm{A} \beta$ immunization caused a striking reduction in total $\mathrm{A} \beta$ levels in both the cortex $(F=17.9$; $\mathrm{df}=1 / 72 ; p<0.001)$ and hippocampus $(F=9.2 ; \mathrm{df}=1 / 72 ; p<$ $0.005)$ and in $\mathrm{A} \beta_{42}$ levels in both the cortex $(F=24.2 ; \mathrm{df}=1 / 75$; $p<0.001)$ and hippocampus $(F=11.1 ; \mathrm{df}=1 / 75 ; p<0.005)$ compared with that in age-matched MPL-AF-treated PDAPP mice. The longer period of immunization in the prevention study (9 months) resulted in a lower total $A \beta$ level than that in the reversal study ( 5 months) in both cortex $(F=10.1 ; \mathrm{df}=1 / 72 ; p<$ $0.005 ; 65.2$ vs $37.8 \%)$ and hippocampus $(F=7.1 ; \mathrm{df}=1 / 72 ; p<$ $0.05 ; 45.9$ vs $19.5 \%)$ and a lower level of $\mathrm{A} \beta_{42}$ in both the cortex $(F=6.6 ; \mathrm{df}=1 / 72 ; p<0.05 ; 54.6$ vs $45.2 \%)$ and hippocampus $(F=7.1 ; \mathrm{df}=1 / 72 ; p<0.05 ; 47.0$ vs $22.9 \%)$. The absolute $\mathrm{A} \beta$ levels for the hippocampus are higher than for the cortex. These overall reductions in $\mathrm{A} \beta$ levels are substantial and highly significant. Thus, the results from this large-scale study indicate that active $A \beta$ immunization effectively suppresses $A \beta$ accumulation in the brain of PDAPP mice subjected to behavioral training.

\section{Correlations between $\mathrm{A} \boldsymbol{\beta}$ levels and behavioral performance}

Despite immunization having no overall effect on the rate at which PDAPP mice could learn, we examined whether there was any correlation between $\mathrm{A} \beta$ levels and behavioral performance. Because the serial spatial learning task is hippocampal dependent but may involve information storage in cortex and because high mutant $\mathrm{A} \beta$ levels are likely to be correlated with neuronal dysfunction, it was expected that correlations would be seen between the behavioral performance of PDAPP mice and both hippocampal and cortical $A \beta$. In practice, a more complex pattern emerged. In non-immunized PDAPP mice, there was no relationship between performance and $A \beta$ levels (Fig. 5). However, in treated PDAPP animals in which the overall levels of $A \beta$ failed to accumulate, a relationship began to emerge. In the prevention study (Fig. 5, top row; Table 2), significant correlations were observed between total $\mathrm{A} \beta$ levels in both hippocampus and cortex with both trials to criterion (data shown only in Table 2) and learning capacity, the highest value being $r=-0.624$ between learning capacity and total $\mathrm{A} \beta$ in hippocampus $(p<0.01)$. Because a single data point in Figure 5, $A$ and $B$, may have been disproportionately contributing to these significant correlations, Spearman's rank correlations were also calculated, and both were still significant $(r=-0.552, p<0.025$ for cortical A $\beta$; and $r=$ $-0.563, p<0.025$ for hippocampal A $\beta$ ). In the reversal study, a similar trend was apparent (Fig. $5 C, D$; Table $2 A$ ). There was, however, no correlation between performance and $\mathrm{A} \beta$ levels in MPL-AF-treated mice (Fig. 5, bottom row; Table $2 A$ ).

\section{Effective learning in animals with low $\mathrm{A} \beta$ levels}

Across the full set of 76 PDAPP mice, there were a number of untreated animals with high $\mathrm{A} \beta$ levels who nonetheless displayed 
Table 1. Total $A \boldsymbol{\beta}$ and $A \boldsymbol{\beta}_{42}$ levels in the cortex and hippocampus of PDAPP mice and amyloid titer response

\begin{tabular}{|c|c|c|c|c|c|c|}
\hline & \multicolumn{2}{|c|}{$A \beta$-immunized PDAPP } & \multicolumn{2}{|c|}{ MPL-AF-treated PDAPP } & \multicolumn{2}{|c|}{$\%$ of decrease } \\
\hline & Prevention & Reversal & Prevention & Reversal & Prevention & Reversal \\
\hline \multicolumn{7}{|l|}{ Cortex } \\
\hline \multicolumn{7}{|l|}{ Total $A \beta$} \\
\hline$n$ & 17 & 24 & 17 & 18 & & \\
\hline $\operatorname{Mean}(\mathrm{ng} / \mathrm{g})$ & 2109 & 5188 & 6068 & 8342 & 65.2 & 37.8 \\
\hline SEM & 464 & 876 & 1036 & 749 & & \\
\hline \multicolumn{7}{|l|}{$\mathrm{A} \beta_{42}$} \\
\hline$n$ & 17 & 24 & 17 & 18 & & \\
\hline Mean $(n g / g)$ & 2296 & 3779 & 5058 & 6902 & 54.6 & 45.3 \\
\hline SEM & 506 & 631 & 799 & 562 & & \\
\hline \multirow{2}{*}{\multicolumn{7}{|c|}{$\begin{array}{c}\text { Hippocampus } \\
\text { Total A } \beta\end{array}$}} \\
\hline & & & & & & \\
\hline$n$ & 17 & 24 & 17 & 18 & & \\
\hline $\operatorname{Mean}(\mathrm{ng} / \mathrm{g})$ & 10379 & 18394 & 19199 & 22849 & 45.9 & 19.5 \\
\hline SEM & 1904 & 2164 & 2562 & 1868 & & \\
\hline \multicolumn{7}{|l|}{$A \beta_{42}$} \\
\hline$n$ & 17 & 24 & 17 & 18 & & \\
\hline $\operatorname{Mean}(\mathrm{ng} / \mathrm{g})$ & 10106 & 17744 & 19068 & 23026 & 47.0 & 22.9 \\
\hline \multirow[t]{3}{*}{ SEM } & 1775 & 2034 & 2725 & 1983 & & \\
\hline & \multicolumn{2}{|c|}{$A \beta$-immunized PDAPP } & \multicolumn{2}{|c|}{$\mathrm{A} \beta$-immunized non- $\mathrm{Tg}$} & & \\
\hline & Prevention & Reversal & Prevention & Reversal & & \\
\hline \multicolumn{7}{|c|}{ Amyloid titer response } \\
\hline$n$ & 17 & 24 & 17 & 22 & & \\
\hline Mean & 9662 & 2644 & 6769 & 1809 & & \\
\hline SEM & 2365 & 214 & 860 & 196 & & \\
\hline
\end{tabular}

a high learning capacity score. This was not observed in the immunized PDAPP group. To the contrary, in this group, the animals that displayed particularly effective learning all had very low total $\mathrm{A} \beta$ and $\mathrm{A} \beta_{42}$ levels (Fig. 5). Paradoxically, despite no overall behavioral effect of immunization, there seemed to be (1) a change in the distribution of animals as a function of levels of $\mathrm{A} \beta$ levels that (2) might be associated with a subtle but detectable alteration in behavioral phenotype.

Accordingly, in the next step of the analysis, we examined all immunized $(n=41)$ and untreated $(n=35)$ PDAPP animals by stratifying them into subgroups reflecting their varied levels of cortical and hippocampal A $\beta$. A Pearson's $\chi^{2}$ test of the distribution of mice by category as shown in Table 3 was significant (for cortical total $\mathrm{A} \beta, \chi^{2}=10.96, p<0.025$; for hippocampal total $\left.\mathrm{A} \beta, \chi^{2}=9.82, p<0.025\right)$. More critical is whether the number of mice in the subgroups with lowest $A \beta$ levels differed as a function of treatment. Pearson's $\chi^{2}$ tests for total $A \beta$ levels indicate that immunization produced a significantly larger number of mice with very low levels of $A \beta$ (for the subgroup of $<1000 \mathrm{ng} / \mathrm{g}$ total $\mathrm{A} \beta$ in the cortex: $\chi^{2}=4.02, p<0.05$; for the subgroup of $<6000$ $\mathrm{ng} / \mathrm{g}$ total $\mathrm{A} \beta$ in the hippocampus: $\left.\chi^{2}=8.05, p<0.01\right)$. Although this merely confirms the effectiveness of immunization in reducing $\mathrm{A} \beta$, this subgrouping by category enabled us to replot the learning capacity data by subgroup, together with the same data for the non-Tg animals (Fig. 6). The nine PDAPP animals that showed cortical total $\mathrm{A} \beta$ levels of $<1000 \mathrm{ng} / \mathrm{g}$ formed a subgroup that learned the series of platform locations at a rate $(8.78 \pm 0.43$ locations in $10 \mathrm{~d})$ that was not significantly different from non-Tg controls ( $8.99 \pm 0.13$ locations; NS) (Fig. 6 A). A set of orthogonal comparisons for all of the PDAPP animals also revealed that the medium, high, and very high $\mathrm{A} \beta$ subgroups did not differ with respect to learning capacity $(F<1)$ and performed significantly worse than the very low $\mathrm{A} \beta$ subgroup $(F=10.9$; $\mathrm{df}=1 / 39 ; p<0.005)$. A similar analysis of the 13 PDAPP animals showing hippocampal total $A \beta$ levels of $<6000 \mathrm{ng} / \mathrm{g}$ also indi- cated that they were not significantly different from non-Tg controls (Fig. 6B). Orthogonal comparisons again revealed that the medium, high, and very high subgroups did not differ $(F<1)$, with the very low subgroup $(8.31 \pm 0.50$ locations; $n=13)$ performing significantly better than these subgroups $(F=9.90 ; \mathrm{df}=$ $1 / 39 ; p<0.005)$ and not differing from the non-Tg controls (NS). Thus, immunization unmasks a relationship between $\mathrm{A} \beta$ levels and performance that, intriguingly, is not present in the untreated animals.

\section{$\mathrm{A} \beta$ antibody titer responses and spatial learning}

An additional immunological analysis was also conducted on the serum anti-A $\beta$ titer responses in all animals tested in the water maze. Comparison of the immunized animals in the prevention and reversal experiments indicated that the longer period of $\mathrm{A} \beta$ treatment produced more anti-A $\beta$ activity than the shorter treatment $(F=29.64$; $\mathrm{df}=1 / 75 ; p<0.001)$ (Table 1$)$. Immunized PDAPP mice did not produce more anti-A $\beta$ activity than immunized non-Tg mice $(F=2.87 ; \mathrm{df}=1 / 75 ; p>0.05)$. In parallel with their higher antibody titer, the entire cohort of immunized PDAPP animals exhibited a highly significant correlation between antibody titer and learning capacity (Spearman's $r=$ $0.443 ; p=0.005$ ) (Table 2). No correlation between titer and learning capacity was observed in non-Tg mice (Spearman's $r=$ 0.116 ; $p>0.4)$. Despite the overall relationship, the correlation between antibody titer and learning capacity did not reach significance when immunized PDAPP mice from the prevention and reversal groups were considered separately (Table 2). Although immunized PDAPP mice in the prevention study exhibited lower $\mathrm{A} \beta$ levels and higher antibody titers compared with those in the PDAPP reversal study (see above), no relationship was observed between antibody titer and $\mathrm{A} \beta$ levels (Table 2 ).

It has been reported recently that human patients with high $\mathrm{A} \beta$ antibody titer responses displayed less cognitive decline over time than non-antibody responders (Gilman et al., 2005). We 
A. Prevention study: LC vs Cortical total $A \beta$ in immunized PDAPP mice

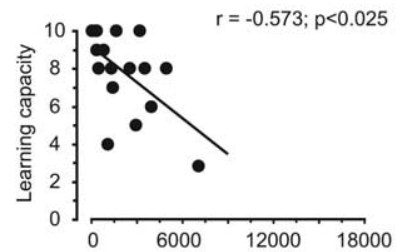

C. Reversal study: LC vs Cortical total $A \beta$ in immunized PDAPP mice

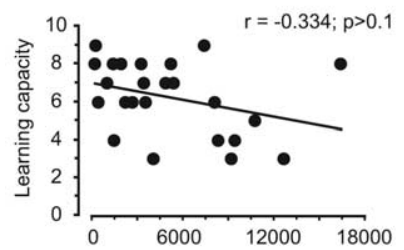

E Combined: $L C$ vs cortical total $A \beta$ in all MPL-treated PDAPP mice

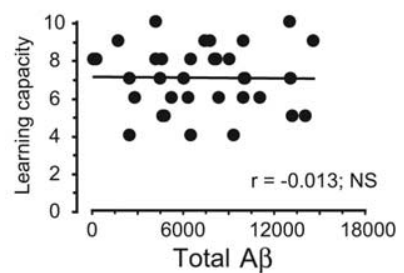

B. Prevention study: LC vs Hippocampal total $A \beta$ in immunized PDAPP mice.

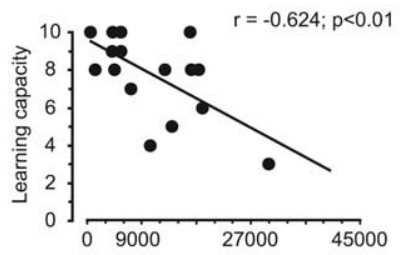

D. Reversal study: LC vs hippocampal total $A \beta$ in immunized PDAPP mice

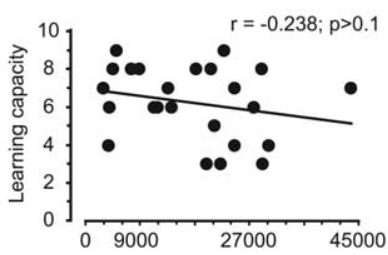

F. Combined: LC vs hippocampal total $A B$ in all MPL-treated PDAPP mice

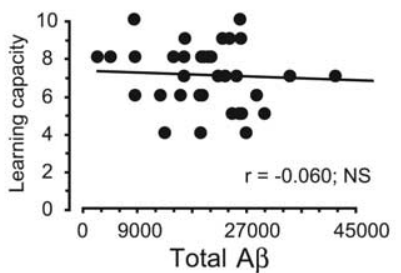

Figure 5. Correlation between $A \beta$ levels and learning capacity. $\boldsymbol{A}, \boldsymbol{B}$, Prevention study. Analysis of the relationship between cortical $(\boldsymbol{A})$ and hippocampal $(\boldsymbol{B})$ total $A \beta$ levels and learning capacity $(\mathrm{LC})$ revealed a significant negative correlation. That is, animals with very low $A \beta$ levels learned a higher number of platform locations in $10 \mathrm{~d}$. $\boldsymbol{C}, \boldsymbol{D}$, Reversal study. A similar analysis revealed a trend toward negative correlations between cortical and hippocampal $A \beta$ levels and learning capacity, but these were not significant. $\boldsymbol{E}, \boldsymbol{F}$, Combined MPL-AF-treated PDAPP animals. No relationships were observed between $A \beta$ levels and performance in adjuvant- treated animals.

Table 2. Correlation coefficients between $A \boldsymbol{\beta}$ and antibody titer levels and serial spatial learning performance

\begin{tabular}{lll}
\hline & Trials to criterion & Learning capacity \\
\hline Hippocampus & & \\
Total $A \beta$ & & \\
$\quad$ Prevention $(n=17)$ & $0.582^{*}$ & $-0.624^{* *}$ \\
$\quad$ Reversal $(n=24)$ & 0.323 & -0.238 \\
MPL-AF treated $(n=35)$ & 0.071 & -0.06 \\
A $\beta_{42}$ & & \\
Prevention & 0.447 & -0.537 \\
Reversal & 0.367 & -0.284 \\
MPL-AF treated & 0.024 & -0.046 \\
Cortex & & \\
Total A $\beta$ & & $-0.573^{*}$ \\
Prevention & $0.554^{*}$ & -0.334 \\
Reversal & 0.281 & -0.013 \\
MPL-AF treated & 0.144 & \\
$A \beta_{42}$ & & -0.352 \\
Prevention & 0.317 & $-0.421^{*}$ \\
Reversal & 0.375 & -0.028 \\
MPL-AF treated & 0.145 & 0.317 \\
Antibody titer & & 0.072 \\
Prevention & -0.231 & \\
Reversal & 0.108 & \\
\hline
\end{tabular}

${ }^{*} p<0.05 ;{ }^{* *} p<0.01$.

Table 3. Distribution of numbers of PDAPP mice into categories as a function of total $A \boldsymbol{\beta}$ levels

\begin{tabular}{lrrrrr}
\hline Cortex & \multicolumn{10}{c}{} \\
\hline Total $A \beta$ (ng/g) & $<1000$ & $<2500$ & $<5000$ & $>5000$ & Total \\
A $\beta$-immunized PDAPP & $9^{*}$ & 9 & 12 & 11 & 41 \\
MPL-AF-treated PDAPP & 2 & 4 & 7 & 22 & 35 \\
Hippocampus & & & & & \\
Total $A \beta$ (ng/g) & $<6000$ & $<13000$ & $<20000$ & $>20000$ & Total \\
A $\beta$-immunized PDAPP & $13^{*}$ & 7 & 8 & 13 & 41 \\
MPL-AF-treated PDAPP & 2 & 4 & 10 & 19 & 35 \\
\hline
\end{tabular}

${ }^{*} p<0.05$.

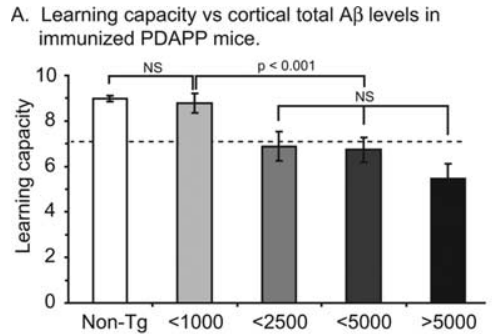

B. Learning capacity vs hippocampal total $A \beta$ levels in immunized PDAPP mice.

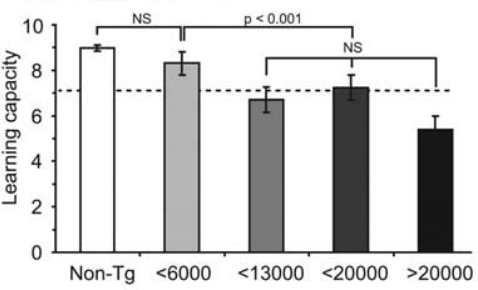

C. Learning capacity stratified by $A B$ titer responses in immunized PDAPP mice.

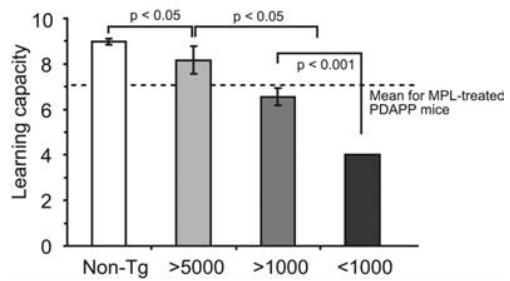

Figure 6. Learning capacity as a function of $A \beta$ levels and $A \beta$ titers. $A$, The PDAPP mice (immunized and untreated) were subdivided with respect to cortical $A \beta$ levels. These data reveal that the subgroup with the very lowest $A \beta$ levels were indistinguishable from non- $\mathrm{Tg}$ controls and better than PDAPP mice with higher $A \beta$ levels. $B$, The PDAPP mice (immunized and untreated) were subdivided with respect to hippocampal $A \beta$ levels. The subgroup with the very lowest $A \beta$ levels was indistinguishable from non-Tg controls. $C$, The PDAPP mice (immunized) were subdivided with respect to $A \beta$ titers. A relationship between antibody titer and performance was observed, but the subgroup with the highest antibody response was still impaired relative to non-Tg controls. Note an apparently exacerbated impairment in immunized mice with a low antibody titer.

therefore analyzed spatial learning stratified by $\mathrm{A} \beta$ antibody titer responses in all immunized PDAPP mice. We sorted these animals into four categories: high responders (titers $>5000$ ), midrange responders $(1000<$ titers $<5000)$, low responders $(100<$ titers $<1000)$, and nonresponders $(<100)$. After either 5 or 9 month treatment with AN1792, most mice showed a high or midrange level of anti-A $\beta$ titer response. Only two mice (one in prevention study and one in reversal) displayed $<1000$ titer responses (low responders), and there were no nonresponders. An ANOVA of learning capacity revealed a significant difference between these three different subgroups of immunized PDAPP an- 
imals $(F=5.1 ; \mathrm{df}=2 / 38 ; p<0.05)$ (Fig. $6 C)$, indicating that $\mathrm{A} \beta$ titer high responders displayed better learning than midrange or low responders. However, the measure does not appear to be that sensitive because the performance of the $A \beta$ titer highresponders group did not differ significantly from that of nonimmunized PDAPP mice ( $p=0.072$ ) and, additionally, was still slightly poorer than non-Tg controls ( $p<0.05$, two-tailed $t$ test). These data parallel those obtained using $\mathrm{A} \beta$ levels but indicate that a high antibody titer is no guarantee that learning will be fully rescued in PDAPP mice.

\section{Discussion}

The main new finding is that a therapeutic rescue of spatial learning can occur in a subset of PDAPP mice in proportion to the apparent effectiveness of immunization in suppressing $A \beta$ accumulation in the brain. This positive finding emerges, however, from a set of intriguingly paradoxical results. Neither short- nor long-term immunization against human $A \beta$ had any overall effect on the rate of learning of a series of spatial tasks. However, we anticipated at the outset that active immunization with $\mathrm{A} \beta_{42}$ was likely to have a varied effect across animals, achieving very low levels of $\mathrm{A} \beta$ only in a subset of our transgenic mice. This was observed, notably in animals given long-term treatment beginning at an age before overt amyloid plaque deposition. A significant correlation was then unmasked between both total $\mathrm{A} \beta$ and $\mathrm{A} \beta_{42}$ levels and performance. Moreover, subsets of immunized PDAPP mice with very low A $\beta$ levels ( $n=9$ for cortex, and $n=13$ for hippocampus) were behaviorally indistinguishable from wild-type controls. There was no evidence of a relationship between learning ability and $\mathrm{A} \beta$ levels in untreated PDAPP mice. These findings are consistent with the notion that an active immunization therapy can be effective in an animal model of $\mathrm{AD}$ that involves five to seven times overexpression of human mutant $\mathrm{A} \beta$.

\section{Impact of immunization}

The apparent "null result" in the overall analysis of the learning data were not because immunization was ineffective. First, ELISA measurements revealed a significantly lower level of total $A \beta$ and $\mathrm{A} \beta_{42}$ in $\mathrm{A} \beta$-immunized PDAPP compared with MPL-AF-treated PDAPP animals, consistent with Schenk et al. (1999). Second, immunized PDAPP mice showed an antibody titer response. Third, there was significant redistribution of PDAPP mice between the $\mathrm{A} \beta$-treated and MPL-AF-treated groups when sorted into subcategories defined according to both cortical and hippocampal total $\mathrm{A} \beta$ levels.

However, although a subset of PDAPP mice with low A $\beta$ levels behaved like wild-type controls in the learning task, there was no overall effect of immunization on cognitive function. This is puzzling because it would be expected that the overall group mean for the treated PDAPP group should show at least a trend toward being different from that of the untreated PDAPP group. The absence of an overall effect of immunization might be explained by the small number of immunized PDAPP mice with moderate to high $\mathrm{A} \beta$ levels that performed poorly in the water maze, raising the specter of potential risks to function when using active immunization.

\section{Variation in the effectiveness of active immunization}

A separate issue is the lack of a significant correlation between $A \beta$ levels and performance in the control-treated PDAPP mice. However, this is not surprising, and there has been recent interest in distinguishing the potentially deleterious effects of distinct forms on cognitive function. A significant correlation between $\mathrm{A} \beta$ levels and cognitive decline is not always found (Arriagada et al., 1992; Hyman and Tanzi, 1992; Gomez-Isla et al., 1997; Giannakopoulos et al., 2003; Guillozet et al., 2003). A possible limitation in interpreting findings from mice with transgenic overexpression of human mutant $A \beta$ is that variation in levels that are massively overexpressed may not be physiologically very meaningful. However, if a treatment such as immunization is successful in limiting the accumulation of $\mathrm{A} \beta$ considerably, physiologically meaningful correlations may then be unmasked that could be mechanistically insightful. If $A \beta$ is a causative factor in dysfunction of $\mathrm{AD}$, it is reasonable to expect that "rescue" of cognitive function could only occur if the putative therapy succeeded in reducing $\mathrm{A} \beta$ levels massively. This is because any lesser reduction would still leave individual mice with an overexpression of the human mutant gene. On this view, finding rescue in only a subset of PDAPP mice is arguably more consistent with the amyloid cascade hypothesis than findings in which functional rescue is observed without such a large decrease (Hardy and Allsop, 1991; Selkoe, 1991, 2002). That we only observed significant rescue in the prevention study is also consistent with the notion that maintaining very low $A \beta$ levels over a long period is better for maintaining effective cognitive function. Thus, although the number of animals $(n=9$ for cortical total $\mathrm{A} \beta ; n=13$ for hippocampal total $\mathrm{A} \beta$ ) in which these effects were observed is small relative to the total number of immunized PDAPP animals tested $(n=41)$, there is a consistency about the behavioral and biochemical phenotype that they displayed.

There is a second possibility for our failure to find an overall positive immunization effect. A recent study has shown that a soluble form of $\mathrm{A} \beta$ assembly, termed $\mathrm{A} \beta^{\star} 56$, contributes to cognitive deficits in Tg2576 mice (Lesne et al., 2006). Because our ELISA detected total $\mathrm{A} \beta$, both soluble and insoluble, we do not know whether active $A \beta$ immunization effectively reduces the soluble $A \beta$ oligomers as well. If so, a statistically detectable relationship may become apparent when the levels of this species are reduced to near zero in a subset of mice, i.e., only in those animals that in our ELISAs would have shown very low levels of total $\mathrm{A} \beta$. Our findings are therefore consistent with the emerging idea that different species of $\mathrm{A} \beta$ promote neuronal dysfunction in a differential manner. It would be valuable in future "proof-of-concept" treatment studies to include analyses of different oligomeric species of $\mathrm{A} \beta$.

\section{Duration and timing of immunization}

Significant rescue of learning capacity occurred in the prevention study with administration of AN1792 at 7 months of age. It is possible that even earlier $A \beta$ immunization, i.e., $\sim 2$ months as by Schenk et al. (1999), might help prevent the functional damage to synapses that has been linked to abnormal accumulation of $\mathrm{A} \beta$ (Selkoe, 2002; Kamenetz et al., 2003), whereas later A $\beta$ immunization would be expected to be less effective. Consistent with this idea, active $A \beta$ immunization using 16 -month-old presenilin 1/APP Tg mice with four biweekly immunizations revealed no rescue of impaired learning when retesting in a radial-arm water maze was performed at 18 months (Austin et al., 2003).

\section{Comparison with other studies}

The statistical power of animal studies requires careful consideration, and we feel ethically justified in having used so many animals to complete this study. Only by running a large study $(n=$ 150 ) were we able to unmask a subtle impact that $A \beta$ immunization. Recent criticism of some animal therapeutic studies (e.g., 
models of stroke) has focused on the use of overly small group sizes (Sandercock and Roberts, 2002; Pound et al., 2004). We share this concern about "under-powered" animal studies. The recent report by Billings et al. (2005) using $>250$ mice is consistent with this perspective.

The variability of $A \beta$ levels in treated PDAPP animals is also relevant. Genetic background can significantly affect $\mathrm{A} \beta$ metabolism and $\mathrm{A} \beta$ deposition in different mouse strains expressing similar levels of APP holoprotein (Lehman et al., 2003). Thus, the more complex genetic makeup of the triple-cross background strain used with the PDAPP mice may contribute to their variability in $\mathrm{A} \beta$ metabolism and deposition and reaction to immunization.

Our findings may seem inconsistent with those of previously published reports for which positive overall effects of immunization were seen with water maze reversal learning, a radial water maze task, and novel object recognition (Janus et al., 2000; Morgan et al., 2000; Dodart et al., 2002; Kotilinek et al., 2002; Billings et al., 2005; Comery et al., 2005; Hartman et al., 2005; Maier et al., 2006; Wilcock et al., 2006). Passive A $\beta$ immunotherapy may be more effective in rescuing cognitive deficits in APP Tg mice (Dodart et al., 2002; Kotilinek et al., 2002; Billings et al., 2005; Comery et al., 2005; Hartman et al., 2005; Wilcock et al., 2006). The discrepancies between our and the other studies may reflect group sizes, which were typically smaller in earlier studies, the presence of an age-independent deficit in PDAPP mice that may be unrelated to $\mathrm{A} \beta$ levels, the effectiveness of active versus passive $\mathrm{A} \beta$ immunization, and/or the differential sensitivity of various behavioral tasks. The serial spatial learning task (Chen et al., 2000) is, for example, more sensitive in revealing age-related learning deficits than a standard reference memory training protocol (Justice and Motter, 1997). It is for this reason that we have argued for the use of episodic-like tasks such as the radial-arm water maze and serial spatial learning task in phase 1 studies (Morgan et al., 2000; Morris, 2001).

\section{Implications with respect to human studies}

Because of the unexpected meningoencephalitis caused by AN1792, the first clinical immunization study of AD patients was halted (Schenk, 2002). Neuropathological observations indicate that immunization is associated with reduced plaques in the human brain (Nicoll et al., 2003). A subset of 20 AN1792immunized patients that were identified as $A \beta$ titer responders in the Zurich cohort of the AN1792 clinical trial showed a reduced rate of decline of cognitive function (Hock et al., 2003). It has been reported that, although analysis of the full 300 patients of the AN1792 study failed to reveal overall differences between placebo and immunized patients across a range of cognitive tests, a subset of 59 patients that were antibody responders showed a lesser decline, relative to placebo controls, in one neuropsychological test battery (Gilman et al., 2005). In our animal study, we find that a subset of immunized PDAPP mice with very high $\mathrm{A} \beta$ titer responses displayed better spatial learning than low A $\beta$ titer responders. Furthermore, our findings suggest that active $A \beta$ immunization can successfully restore spatial learning in a mouse model of $\mathrm{AD}$ if the brain $\mathrm{A} \beta$ levels fail to accumulate. Together, human and animal studies collectively provide additional grounds for confidence that immunization is a viable approach to novel therapeutics for AD.

\section{References}

Arriagada P, Growdon J, Hedley-Whyte E, Hyman B (1992) Neurofibrillary tangles but not senile plaques parallel duration and severity of Alzheimer's disease. Neurology 42:631-639.
Austin L, Arendash GW, Gordon MN, Diamond DM, DiCarlo G, Dickey C, Ugen K, Morgan D (2003) Short-term beta-amyloid vaccinations do not improve cognitive performance in cognitively impaired APP + PS1 mice. Behav Neurosci 117:478-484.

Bacskai BJ, Kajdasz ST, Christie RH, Carter C, Games D, Seubert P, Schenk D, Hyman BT (2001) Imaging of amyloid-beta deposits in brains of living mice permits direct observation of clearance of plaques with immunotherapy. Nat Med 7:369-372.

Bard F, Cannon C, Barbour R, Burke RL, Games D, Grajeda H, Guido T, Hu K, Huang J, Johnson-Wood K, Khan K, Kholodenko D, Lee M, Lieberburg I, Motter R, Nguyen M, Soriano F, Vasquez N, Weiss K, Welch B, et al. (2000) Peripherally administered antibodies against amyloid betapeptide enter the central nervous system and reduce pathology in a mouse model of Alzheimer disease. Nat Med 6:916-919.

Bartus RT (2000) On neurodegenerative diseases, models, and treatment strategies: lessons learned and lessons forgotten a generation following the cholinergic hypothesis. Exp Neurol 163:495-529.

Bartus RT, Dean RI, Beer B, Lippa AS (1982) The cholinergic hypothesis of geriatric memory dysfunction. Science 217:408-414.

Billings LM, Oddo S, Green KN, McGaugh JL, Laferla FM (2005) Intraneuronal Abeta causes the onset of early Alzheimer's disease-related cognitive deficits in transgenic mice. Neuron 45:675-688.

Chen G, Chen KS, Knox J, Inglis J, Bernard A, Martin SJ, Justice A, McConlogue L, Games D, Freedman SB, Morris RG (2000) A learning deficit related to age and beta-amyloid plaques in a mouse model of Alzheimer's disease. Nature 408:975-979.

Comery TA, Martone RL, Aschmies S, Atchison KP, Diamantidis G, Gong X, Zhou H, Kreft AF, Pangalos MN, Sonnenberg-Reines J, Jacobsen JS, Marquis KL (2005) Acute gamma-secretase inhibition improves contextual fear conditioning in the Tg2576 mouse model of Alzheimer's disease. J Neurosci 25:8898-8902.

DeMattos RB, Bales KR, Cummins DJ, Dodart J-C, Paul SM, Holtzman DM (2001) Peripheral anti-Abeta antibody alters CNS and plasma Abeta clearance and decreases brain Abeta burden in a mouse model of Alzheimer's disease. Proc Natl Acad Sci USA 98:8850-8855.

Dodart JC, Bales KR, Gannon KS, Greene SJ, DeMattos RB, Mathis C, DeLong CA, Wu S, Wu X, Holtzman DM, Paul SM (2002) Immunization reverses memory deficits without reducing brain Abeta burden in Alzheimer's disease model. Nat Neurosci 5:452-457.

Duff K, Eckman C, Zehr C, Yu X, Prada CM, Perez-tur J, Hutton M, Buee L, Harigaya Y, Yager D, Morgan D, Gordon MN, Holcomb L, Refolo L, Zenk B, Hardy J, Younkin S (1996) Increased amyloid-beta42(43) in brains of mice expressing mutant presenilin 1. Nature 383:710-713.

Games D, Adams D, Alessandrini R, Barbour R, Berthelette P, Blackwell C, Carr T, Clemens J, Donaldson T, Gillespie F, Guido T, Hagopian S, Johnson-Wood K, Khan K, Lee M, Leibowitz P, Lieberburg I, Little S, Masliah E, McConlogue L, et al. (1995) Alzheimer-type neuropathology in transgenic mice overexpressing $\mathrm{V} 717 \mathrm{~F}$ beta-amyloid precursor protein. Nature 373:523-527.

Giannakopoulos P, Herrmann FR, Bussiere T, Bouras C, Kovari E, Perl DP, Morrison JH, Gold G, Hof PR (2003) Tangle and neuron numbers, but not amyloid load, predict cognitive status in Alzheimer's disease. Neurology 60:1495-1500.

Gilman S, Koller M, Black RS, Jenkins L, Griffith SG, Fox NC, Eisner L, Kirby L, Rovira MB, Forette F, Orgogozo JM (2005) Clinical effects of Abeta immunization (AN1792) in patients with $\mathrm{AD}$ in an interrupted trial. Neurology 64:1553-1562.

Gomez-Isla T, Hollister R, West H, Mui S, Growdon JH, Petersen RC, Parisi JE, Hyman BT (1997) Neuronal loss correlates with but exceeds neurofibrillary tangles in Alzheimer's disease. Ann Neurol 41:17-24.

Guillozet AL, Weintraub S, Mash DC, Mesulam MM (2003) Neurofibrillary tangles, amyloid, and memory in aging and mild cognitive impairment. Arch Neurol 60:729-736.

Hardy J, Allsop D (1991) Amyloid deposition as the central event in the aetiology of Alzheimer's disease. Trends Pharmacol Sci 12:383-388.

Hartman RE, Izumi Y, Bales KR, Paul SM, Wozniak DF, Holtzman DM (2005) Treatment with an amyloid-beta antibody ameliorates plaque load, learning deficits, and hippocampal long-term potentiation in a mouse model of Alzheimer's disease. J Neurosci 25:6213-6220.

Hock C, Konietzko U, Streffer JR, Tracy J, Signorell A, Muller-Tillmanns B, Lemke U, Henke K, Moritz E, Garcia E (2003) Antibodies against beta- 
amyloid slow cognitive decline in Alzheimer's disease. Neuron 38:547-554.

Hsiao K, Chapman P, Nilsen S, Eckman C, Harigaya Y, Younkin S, Yang F, Cole G (1996) Correlative memory deficits, Abeta elevation, and amyloid plaques in transgenic mice. Science 274:99-103.

Hyman BT, Tanzi RE (1992) Amyloid, dementia and Alzheimer's disease. Curr Opin Neurol Neurosurg 5:88-93.

Janus C, Pearson J, McLaurin J, Mathews PM, Jiang Y, Schmidt SD, Chishti MA, Horne P, Heslin D, French J, Mount HT, Nixon RA, Mercken M, Bergeron C, Fraser PE, St George-Hyslop P, Westaway D (2000) Abeta peptide immunization reduces behavioural impairment and plaques in a model of Alzheimer's disease. Nature 408:979-982.

Justice A, Motter R (1997) Behavioral characterization of PDAPP transgenic Alzheimer mice. Soc Neurosci Abstr 23:636.636.

Kamenetz F, Tomita T, Hsieh H, Seabrook G, Borchelt D, Iwatsubo T, Sisodia S, Malinow R (2003) APP processing and synaptic function. Neuron 37:925-937.

Kotilinek LA, Bacskai B, Westerman M, Kawarabayashi T, Younkin L, Hyman BT, Younkin S, Ashe KH (2002) Reversible memory loss in a mouse transgenic model of Alzheimer's disease. J Neurosci 22:6331-6335.

Lehman EJH, Kulnane LS, Gao Y, Petriello MC, Pimpis KM, Younkin L, Dolios G, Wang R, Younkin SG, Lamb BT (2003) Genetic background regulates beta-amyloid precursor protein processing and beta-amyloid deposition in the mouse. Hum Mol Genet 12:2949-2956.

Lesne S, Koh MT, Kotilinek L, Kayed R, Glabe CG, Yang A, Gallagher M, Ashe $\mathrm{KH}$ (2006) A specific amyloid- $\beta$ protein assembly in the brain impairs memory 440:352-357.

Maier M, Seabrook TJ, Lazo ND, Jiang L, Das P, Janus C, Lemere CA (2006) Short amyloid-beta (Abeta) immunogens reduce cerebral Abeta load and learning deficits in an Alzheimer's disease mouse model in the absence of an Abeta-specific cellular immune response. J Neurosci 26:4717-4728.

Mattson MP, Chan SL (2003) Good and bad amyloid antibodies. Science 301:1847-1849.

Morgan D, Diamond DM, Gottschall PE, Ugen KE, Dickey C, Hardy J, Duff K, Jantzen P, DiCarlo G, Wilcock D, Connor K, Hatcher J, Hope C, Gordon M, Arendash GW (2000) Abeta peptide vaccination prevents memory loss in an animal model of Alzheimer's disease. Nature 408:982-985.

Morris R (2001) Episodic-like memory in animals: psychological criteria, neural mechanisms and the value of episodic-like tasks to investigate animal models of neurodegenerative disease. Philos Trans R Soc Lond B Biol Sci 356:1453-1465.

Nicoll JAR, Wilkinson D, Holmes C, Steart P, Markham H, Weller RO (2003) Neuropathology of human Alzheimer disease after immunization with amyloid-beta peptide: a case report. Nat Med 9:448-452.

Orgogozo J-M, Gilman S, Dartigues J-F, Laurent B, Puel M, Kirby LC, Jouanny P, Dubois B, Eisner L, Flitman S, Michel BF, Boada M, Frank A, Hock C (2003) Subacute meningoencephalitis in a subset of patients with AD after Abeta42 immunization. Neurology 61:46-54.

Pound P, Ebrahim S, Sandercock P, Bracken MB, Roberts I (2004) Where is the evidence that animal research benefits humans? BMJ 328:514-517.

Price DL, Borchelt DR, Walker LC, Sisodia SS (1992) Toxicity of synthetic Abeta peptides and modeling of alzheimer's disease. Neurobiol Aging 13:623-625.

Sandercock P, Roberts I (2002) Systematic reviews of animal experiments. Lancet 360:586.

Schenk D (2002) Amyloid-beta immunotherapy for Alzheimer's disease: the end of the beginning. Nat Rev Neurosci 3:824-828.

Schenk D, Barbour R, Dunn W, Gordon G, Grajeda H, Guido T, Hu K, Huang J, Johnson-Wood K, Khan K, Kholodenko D, Lee M, Liao Z, Lieberburg I, Motter R, Mutter L, Soriano F, Shopp G, Vasquez N, Vandevert C, et al. (1999) Immunization with amyloid-beta attenuates Alzheimer-diseaselike pathology in the PDAPP mouse. Nature 400:173-177.

Selkoe DJ (1991) The molecular pathology of Alzheimer's disease. Neuron 6:487-489.

Selkoe DJ (2002) Alzheimer's disease is a synaptic failure. Science 298:789-791.

Sisodia SS (1992) Beta-amyloid precursor protein cleavage by a membranebound protease. Proc Natl Acad Sci USA 89:6075-6079.

Sommer B, Sturchler-Pierrat C, Abramowski D, Wiederhold KH, Calhoun M, Jucker M, Kelly P, Staufenbiel M (2000) Transgenic approaches to model Alzheimer's disease. Rev Neurosci 11:47-51.

Wilcock DM, Alamed J, Gottschall PE, Grimm J, Rosenthal A, Pons J, Ronan V, Symmonds K, Gordon MN, Morgan D (2006) Deglycosylated antiamyloid- $\beta$ antibodies eliminate cognitive deficits and reduce parenchymal amyloid with minimal vascular consequences in aged amyloid precursor protein transgenic mice. J Neurosci 26:5340-5346. 